\title{
Old forest policy and regulatory frameworks in Nova Scotia and New Brunswick with a comparison to British Columbia
}

\author{
by Amy Berry ${ }^{1}$, Amanda Lavers ${ }^{1 *}$ and Lisa Mitchell ${ }^{2}$
}

\begin{abstract}
Old growth forests (OGF) represent ecological continuity and are rich in biodiversity. These unique landscapes are becoming increasingly rare in Canada, especially within the Acadian Forest Region that covers the Maritime Provinces. Less than $1 \%$ of the total forest cover in these provinces is OGF - this is drastically lower than the $55 \%$ represented in British Columbia's Temperate Coastal Rainforest. The authors of this paper conducted a comprehensive comparative analysis of old forest policies and regulatory frameworks in Nova Scotia, New Brunswick and British Columbia to offer recommendations for improving the conservation and stewardship of OGF in the Maritimes. The analysis revealed that in Nova Scotia there is a strong old forest policy underpinned by a quantitative scoresheet, coordinator, and database. In New Brunswick and Nova Scotia the conservation targets are up to $8 \%$ on Crown land, but neither have a regulatory framework nor have evidence of achieving these targets. British Columbia has integrated Forest Stewardship Plans that promote the retention of OGF as legally enforceable tools for licensees in Old Growth Forest Management Areas. Such an approach could prove useful in improving the restoration and conservation of OGF in the Maritime Provinces.
\end{abstract}

Keywords: old growth, forest policy, Acadian Forest Region, comparative legislative analysis, Nova Scotia, New Brunswick, British Columbia, Crown land, old forest scoresheet, conservation, legislation, regulatory framework

\section{RÉSUMÉ}

Les forêts anciennes (old growth forests-OGF) représentent la continuité écologique et montrent une grande biodiversité. Ces paysages uniques sont de plus en plus rares au Canada, tout particulièrement dans la région forestière Acadienne qui couvre les provinces de l'Atlantique. Les OGF représentent moins de $1 \%$ du couvert forestier de ces provinces ce qui est nettement inférieur aux 55 \% de représentation dans la forêt pluviale côtière tempérée de la Colombie-Britannique. Les auteurs de cet article ont effectué une analyse complète du cadre légal et réglementaire sur les vieilles forêts en NouvelleÉcosse, au Nouveau-Brunswick et en Colombie-Britannique en vue de formuler des recommandations pour améliorer la conservation et la gestion des OGF dans les provinces de l'Atlantique. Lanalyse a montré que la Nouvelle-Écosse a une solide politique sur les vieilles forêts appuyée par des données quantitatives spécifiques, un coordonnateur et une base de données. Le Nouveau-Brunswick et la Nouvelle-Écosse se sont donné des cibles de conservation allant jusquà $8 \%$ sur les terres du domaine public, mais ni l'une ni l'autre n’a de cadre réglementaire ni d'indicateur précis pour démontrer latteinte de ces objectifs. La Colombie-Britannique sest dotée de plans de gestion forestière (Forest Stewardship Plans) qui favorisent la rétention des OGF que les titulaires de licences ont l'obligation d'appliquer dans les zones de Forêts anciennes sous aménagement. C'est une approche qui pourrait s’avérer utile pour améliorer la restauration et la conservation des OGF dans les provinces de l'Atlantique.

Mots-clés : vieilles forêts, politique forestière, région forestière Acadienne, analyse comparative des lois, Nouvelle-Écosse, Nouveau-Brunswick, Colombie-Britannique, terres du domaine public, feuille de pointage sur les vieilles forêts, conservation, législation, cadre réglementaire

\footnotetext{
${ }^{1}$ Mersey Tobeatic Research Institute, 9 Mount Merritt Road, PO Box 215, Kempt, Queens County, Nova Scotia, Canada, B0T 1B0

*Amanda.lavers@merseytobeatic.ca

${ }^{2}$ East Coast Environmental Law, 6061 University Avenue, Halifax, Nova Scotia, Canada B3H 4H9
} 


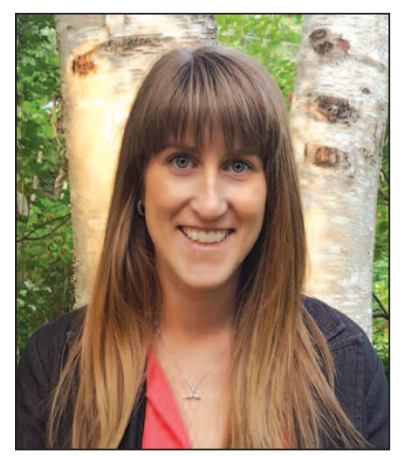

Amy Berry

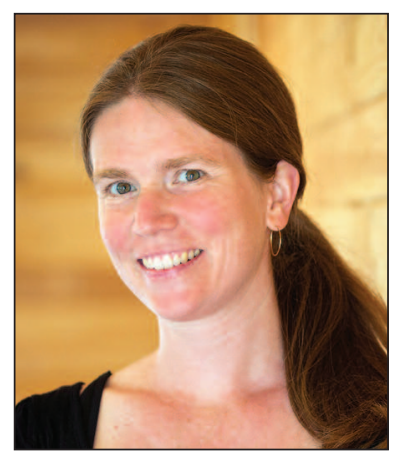

Amanda Lavers

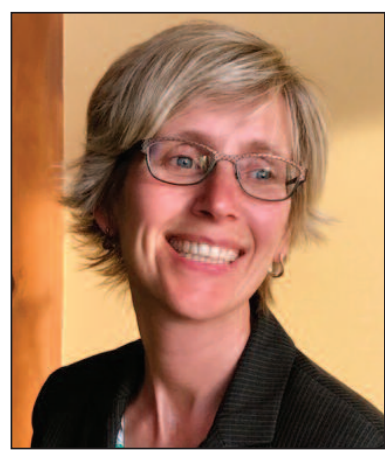

Lisa Mitchell associated with forest management in the Maritimes. Inappropriate forest management strategies in the Acadian Forest Region have resulted in forest stands with even-aged, shortlived species, the degradation of ecological integrity, and the disappearance of old forests (Loo and Ives 2003). The estimated area of OGF in the Maritime Provinces is less than $1 \%$ of the total forest cover. Prior to European settlement, up to $50 \%$ of the forest cover was

\section{Introduction}

Old growth forests have been declining in Canada since European colonization due to the expansion of agriculture and logging (Leckie et al. 2002). In addition to providing ecosystem services and material values such as carbon sequestration (Luyssaert et al. 2008), OGF also provide non-material values (sociocultural, ethical, spiritual or aesthetic) that are often overlooked but have been subject to some analysis in eastern Canada (Moyer et al. 2008).

The Acadian Forest Region covers most of the Maritime Provinces (New Brunswick, Nova Scotia and Prince Edward Island) with some minor exclusion classified as Boreal Forest (Rowe 1972). With a high prevalence of red spruce, the Acadian Forest Region comprises long-lived tree species that regenerate naturally; other common species include: balsam fir, eastern hemlock, eastern white pine, yellow birch, sugar maple and American beech (Mosseler et al. 2003). The World Wildlife Fund has assigned the Acadian Forest Ecoregion Critical/Endangered status (Davis et al. 2017). Moreover, scholars have agreed that the Acadian Forest in southwest Nova Scotia is crucial for ecosystem protection and connectivity for the entirety of the province and the greater Appalachian-Acadian Ecoregion (Beazley et al. 2005).

The definition of OGF has been heavily contested due to the multiple values associated with these unique and special places. Definitions vary in focus from social aspects of OGF (emotional, spiritual, and cultural) to economic determinants (harvesting priority, saw mill value, ecosystem services) to ecological elements (structural, compositional, and process features) (Hilbert and Wiensczyk 2007; Wirth et al. 2009; Pesklevits et al. 2011). For the purpose of this paper we will use the following definition: OGF are typically multilayered, comprising numerous late successional tree species of varying ages and sizes, but are dominated by old overstory trees. They are rich in biodiversity and ecologically continuous; they contain dead trees (both standing and fallen) and other forest debris that are left to decompose naturally; they have little evidence of human disturbance; there is natural regeneration occurring between canopy gaps; and, they function as important wildlife habitats, and nurture healthy soil composition (Mosseler et al. 2003). Some critics have argued that such a definition is not scientific but instead paints a picture of the old forest type typical to the temperate forest biome (Wirth $e t$ al. 2009). However, for the purpose of this paper this definition aligns closely with the definitions used for policy in the jurisdictions examined, and is relevant to the short-comings
OGF (Mosseler et al. 2003). In the province of Nova Scotia, OGF was last recorded to be less 8026 ha of Crown Land (Stewart et al. 2008) which amounts to less than a tenth of a percent of total Crown land. This is much lower than that of the Temperate Coastal Rainforest on the Pacific Coast of British Columbia where OGF constitutes $55 \%$ of total forest cover (Moyer et al. 2008). This stark contrast demonstrates the need for old growth forest conservation in the Maritimes per se but also the conservation of forests with the potential to develop into OGF in the future. In this paper the authors conducted a comparative legislative and policy analysis to understand how best to improve old growth forest policy and legislation in the Maritimes.

\section{Methodology}

Thirty-two comparative analysis criteria were developed and reviewed by leading forest experts, scientists and policy makers in the Maritimes. This permitted jurisdictional comparisons of penalties, evaluation strategies, monitoring programs, public comment, scientific definitions, conformance and other criteria. Using these criteria, six law students analyzed each individual OGF policy, statute and regulation in Nova Scotia, New Brunswick, Ontario, British Columbia, Maine, Massachusetts, and New Hampshire. Following this preliminary analysis, Nova Scotia, New Brunswick and British Columbia were chosen for further analysis due to their unique policy or regulatory frameworks in order to offer recommendations. Two participatory comparative analysis sessions were held to allow forest experts, scientists and policy makers in the Maritimes to provide feedback. This feedback was integrated into the final analysis.

\section{Results and Discussion Nova Scotia}

According to Nova Scotia's Old Forest Policy, which is designed to be quantitative and measureable within a conservation program, Class 1 OGF are "forest stand[s] where 30\% or more of the basal area is in trees 125 years or older, at least half of the basal area is composed of climax species ${ }^{3}$, and total crown closure is a minimum of 30\%" (NSDNR 2012). Nova Scotia does not have a specific regulatory framework to address OGF. Regulation of forests in Nova Scotia is primarily lock, red spruce, white pine, sugar maple, yellow birch and American beech
${ }^{3}$ Climax Species on Zonal Acadian Forest Ecotypes include: hem- 
via the Crown Lands Act (1989), Forests Act (1989), and the Wildife Habitat and Watercourses Protection Regulations under this Act, and the Forest Enhancement Act (1989). The Minister of Natural Resources is responsible for all three statutes. Legislated authority to protect particular areas of land exists in the Special Places Protection Act (1989), the Wilderness Areas Protection Act (1998), and the Conservation Easements Act (2001); however, these statutes do not specifically reference OGF. In August 2012, the Nova Scotia Department of Natural Resources (NSDNR) released Nova Scotia's Old Forest Policy. As stated on page 5 of the policy, the Minister of Natural Resources is responsible for its administration under the authority of the Forests Act and the Crown Lands Act. The policy covers a number of objectives, plans and guidelines, including the objective to establish and sustain an ecologically representative network of old forest and the designation of a Provincial Old Forest Coordinator.

In section 6.1 of Nova Scotia's Old Forest Policy, the province commits to preserving eight percent of the land within each of Nova Scotia's 38 ecodistricts for OGF conservation or restoration. Section 7.0 of the policy provides guidelines for selection of these areas, using an Old Forest Scoresheet. The scoresheet is used to evaluate quantitatively the biophysical conditions of potential old forest stands and to guide management practices. The evaluation strategy examines the stage of forest development, structural attributes, and logging history to determine a score out of 100 (Stewart et al. 2003). This is then reviewed by the Old Forest Coordinator who is responsible for maintaining the Geographic Information Systems database containing this information.

To improve accountability and transparency, in 2014 NSDNR began to post proposed forest harvest blocks on Crown land on its website in advance of all forest harvesting. The decision-making process surrounding forest harvesting and management on Crown land has been critiqued due to a lack of collaboration and consultation which has resulted in mistrust and the perception of a closed policy network (Miller and Nadeau 2016). However, the public accessibility of the harvest information allowed researchers at the Mersey Tobeatic Research Institute in 2014 to bring to NSDNR's attention several Class 1 old forest stands that were proposed for forest harvesting on Crown land. NSDNR staff repeated an old forest assessment at each of these sites; in two of three, management plans were modified and the stands were excluded and replaced with younger sites designated in the GIS old forest database.

Nova Scotia's Old Forest Policy (NSDNR 2012) has many positive attributes as described above, but it is not without its limitations. Although the policy recommends buffers around OGF in section 7.1, there is no evidence that these buffers are being implemented. The GIS database referred to in section 6.2 remains under development five years later. There are currently no provisions in place to ensure that eight percent of the land within each of the 38 ecodistricts is preserved for OGF conservation or restoration. In fact, according to the 2008 Status Report, six ecodistricts did not meet this target (Stewart and Neily 2008). Moreover, although the policy suggests representation of topography typical to a given ecodistrict, it prioritizes the conservation of stands that have the least commercial value whereas it should prioritize the stand with the highest conservation value, or old forest score.
"Forests on steep slopes have different ecological characteristics than those on level ground, and both types of topography should be represented in proportion to percentages that are ecologically normal for the ecodistrict. Within this constraint, preference should be given to forests having the least value for commercial resource use, e.g., inaccessible sites" (NSDNR 2012; p. 6).

The protection of OGF in Nova Scotia is not mandatory and the regulatory framework does not ensure conservation. The protection is spatially implicit, but can be exchanged for others within the same ecodistrict. That said, according to section 6.3 , it is required that any "exchange or replacements of old forest stands be neutral or improve conservation of old forests and their associated ecological processes and biodiversity" (NSDNR 2012; p. 4). There is no guarantee that an area protected within the eight percent of each ecodistrict will remain protected in perpetuity unless it is designated a protected area. Overall, Nova Scotia's Old Forest Policy demonstrates potential for integrating science into the management of OGF areas, but a significant gap still remains between the general intent of the policy and actual conservation results.

\section{New Brunswick}

Like Nova Scotia, New Brunswick does not have a regulatory framework to address OGF. Forest management is addressed by the Crown Lands and Forests Act (NBDNR 1980) and administered by the Minister of Natural Resources. Protection of OGF may be achieved through the Protected Natural Areas Act (NBDNR 2002) and the Conservation Easement Act (NBDNR 2011) with the Minister of Natural Resources being responsible for the administration of these statutes as well. The Crown Lands and Forests Act uses a licensing approach to manage forestry activity on Crown land (at s. 28). According to the New Brunswick Strategy for Crown Lands and Management, this is referred to as results-based forestry, which is considered by the New Brunswick Department of Natural Resources (NBDNR) to be a more efficient and less costly strategy for forest management (NBDNR 2014a).

Under the Crown Lands and Forests Act, crown timber licenses are issued when there is a forest management agreement in place between the Minister and the proposed license holder. Management plans are in place for a 25 -year period and must address a range of issues from timber management to watershed protection (at s. 29).

Any Crown land managed under a timber license agreement is required to be certified under a third party, the Forest Stewardship Council (FSC), Sustainable Forest Initiative (SFI), or Canadian Standards Association (CSA). These certification bodies differ significantly in their priorities and criteria for certification, particularly with regard to the protection of OGF (Sample et al. 2003). In New Brunswick, all Crown lands, 4.2 million hectares in total, are currently certified under SFI (Canadian Council of Forest Ministers 2015. Although this certification body mentions OGF as ecologically important sites (Objective 4) under SFI certification, licensees may still harvest in these areas (SFI 2015). Similarly with CSA, the only mention of OGF is in reference to required discussion topics for public participation processes (CSA Group 2016). In contrast, FSC explicitly mandates protection of OGF in section 9.3.4: "Conservation zones shall be 
established in primordial forests and identified on maps, and shall not be harvested" (FSC 2008; p. 48).

The Crown Lands and Forests Act in New Brunswick does not specifically contemplate the protection of biodiversity or OGF. It does, however, mandate that "objectives" for use of the land be set in the forest management agreement (at s. 29). The Minister of Natural Resources sets timber and non-timber objectives every five years, which must be incorporated into forest management agreements. The current policy includes the objective that: "Functional patches of old forest will be retained across each ecoregion in each of 14 identifiable community types. Objective levels in each ecoregion aim to sustain at least $6-8 \%$ in old age classes of each forest community's total area" (NBDNR 2014b). A provincial government policy released in 2013, Old Forest Community and OldForest Wildlife Habitat Definitions for New Brunswick 2012 (NBDNR 2013) identifies their requirements:

\begin{abstract}
"Old Forest Communities (OFC) are the building blocks of the Province's strategy to supply old-forest conditions on Crown land. Eighteen unique communities, within 7 ecoregions, encompass the full range of naturally occurring old-forest conditions. They are described at the stand level by composition and structure and at the landscape level by patch size. Old-forest Wildlife Habitats $(\mathrm{OFWH})$ are groups of old forest communities that are further described at the stand level by abundance of woody debris and tree cavities, and at the landscape level by patch size and inter-patch distance. OFWHs and their constituent OFCs were defined based on the requirements of the vertebrate species assigned to them" (NBDNR, 2013; p. 1).
\end{abstract}

These definitions incorporate scientific and ecological knowledge which is used to determine the level of conservation. The document identifies 46 of the 137 vertebrate species found in the forests of New Brunswick as dependent on old forest conditions, and lists habitat requirements for each (NBDNR 2013).

In New Brunswick, the protection of old forests is driven by vertebrate wildlife species (NBDNR 2013), and although the current policy incorporates scientific and ecological knowledge, it neglects to take into account other values associated with OGF. Although New Brunswick aims to preserve $6-8 \%$, there is no monitoring program or status to hold the government accountable to this goal. Another limitation associated with New Brunswick's model of forest management is that efficiency, profit and cost-effectiveness are prioritized over the protection of OGF. The harvesting of timber is permitted in OFC and OFWH, as long as the stand structure is maintained both spatially and temporally (NBDNR 2014b; NBDNR 2014c). According to Schedule G-Licensee Performance Evaluation Criteria: should a third party auditor find a non-conformance associated with OFC or OFWH, the punitive damages assigned to the licensee would be an "additional $1 \mathrm{x}$ royalty penalty to be paid on area losses in excess of 5 hectares" and replacement of the area to DNR's satisfaction (NBDNR 2014c). It is problematic that licensees can pay a small fee to cut OFC and OFWH, because OGF areas take decades, centuries or even millennia to re-establish themselves. As with Nova Scotia, this presents a problem for ecological continuity.

\section{British Columbia}

Although British Columbia does not have a statute that specifically relates to OGF there are several provincial statutes and regulations that have a bearing on OGF, including the Land Act (BCFLNRO 1996c) and the Forest and Range Practices Act (BCFLNRO 2002). General forestry regulation, including the granting of logging rights through tenure agreements, is carried out under the Forest Act and regulations. The Minister of Forests, Lands and Natural Resource Operations is responsible for all forestry related legislation in the province. The provincial Land Act is the primary law addressing the disposition and management of Crown land. The Land Act sets out the ways in which Crown land can be managed, including the creation of Crown land reserves that prevent the disposition of Crown land because of a recognized public interest (at s. 15).

The Ecological Reserves Act (BCFLNRO 2016), the Park Act (BCFLNRO 1996b) and the Protected Areas of British Columbia Act (BCFLNRO 2000) each has some capacity to protect OGF. The Protected Areas of British Columbia Act includes Schedules that set out ecological reserves and parks. The Environment and Land Use Act (BCFLNRO 1996a) may also be used to establish a protected area by way of order under the Act.

The Forest Practices Code of British Columbia Act (the "Code") (BCFLNRO 2004b) was the first provincial law to address OGF retention. The Code led to the creation of the Biodiversity Guidebook and the Landscape Unit Planning Guide. While neither is a legal document, they both provide procedures for identification and mapping of Old Growth Management Areas (OGMAs). The guidance material was used in land use plans to identify old growth objectives; these became legally binding when they were issued as orders in accordance with the Code (Environmental Law Centre Clinic 2013).

In 2002, the Forest and Range Practices Act replaced the Code, and the Code orders were retained under the Land Act, which sets government objectives that must be incorporated into forest licenses. Additionally, section 93.4 of the Land Act gave the Minister the authority to set objectives and declare orders for OGMA. The Code era orders and the Land Act orders are enforced through the Forest and Range Practices Act via the requirement for a Forest Stewardship Plan.

As of 2012, approximately 2 million hectares of land were identified under a Land Act OGMA (Forest Practices Board 2012). The orders are not entirely consistent; for example, in some instances the orders are spatial while others are nonspatial. As well, retention following forest cutting can range from 3\% to 70\% (Forest Practices Board 2012).

Land Act OGMA orders are recognized by other provincial resource-based statutes and regulations. For example, the Environmental Protection and Management Regulation under the Oil and Gas Activities Act prescribes the objective "...that operating areas not be located within an old-growth management area unless it will not have a material adverse effect on the old seral stage forest representation within that area" (at s. 7).

The Forest Planning and Practices Regulation (BCFLNRO 2004a) sets out ten government objectives that must be addressed in the legally binding Forest Stewardship Plan. Section 3 of Schedule 1 to the Regulation provides guidance to the licensee on how to address the government objective for wildlife and biodiversity. To meet the landscape based objec- 
tive set out in section 9 of the Regulation the licensee must address:

"... the extent to which wildlife habitat areas, ungulate winter ranges, riparian management areas, scenic areas and other areas established to manage forest resources complement efforts to resemble natural disturbance patterns in a landscape, including old-growth" (Forest Planning and Practices Regulation, Sch. 1, s. 3(1)(c)).

To meet the stand-level objective set out in section 9.1 of the Regulation, the licensee must:

(a) Address the size, structure, amount, location and other characteristics of trees that

(i) Make the trees suitable for wildlife habitat, and

(ii) Have ecological attributes that contribute to stand level biodiversity;

(b) Address the extent to which wildlife habitat areas, ungulate winter ranges, riparian management areas, old growth management areas, scenic areas and other areas established to manage forest resources,

(i) Provide suitable wildlife habitat, and

(ii) Assist in the conservation of stand level biodiversity, including old growth. (Forest Planning and Practices Regulation, Sch. 1, s. 3 (2)).

Subsection $14(3)$ of the Regulation requires that all OGMAs located in a particular development unit be included in a Forest Stewardship Plan. As of 2012, there were approximately 55000 OGMAs totaling 3.9 million hectares of land; however, only $30 \%$ of these have protection under the law through integration into Forest Stewardship Plans (Forest Practices Board 2012). The approach used by British Columbia, although somewhat convoluted, provides a legally enforceable tool for OGF retention. The forest license is enforced via the Forest Range and Practices Act and the Act requires the licensee to complete a Forest Stewardship Plan, including specific protections for OGF.

In 1999 the government of British Columbia undertook a forestry-based pilot project to seek a balance between more efficient and less costly production with the protection of social and environmental values. The pilot project covered 180000 hectares. To implement the project the government passed the Stillwater Pilot Project Regulation (BCFLNRO 2001) under the Forest Practices Code of British Columbia Act, which provided one of the first uses of the publically reviewed Forest Stewardship Plan. The Regulation sets up four forest stewardship zones (timber, habitat, old growth, and recreation and tourism) with specific objectives. The pilot project was required to demonstrate that the Forest Stewardship Plan ensured protection equivalent to that required by the Forest Practices Code of British Columbia Act.

Section 12 of the Stillwater Pilot Project Regulation sets out the management approach with four requirements as follows:

"(i) the management focus is to conserve existing oldgrowth timber, and restore old-growth timber attributes on previously harvested areas; (ii) timber harvesting in old-growth stands will employ a mix of irregular shelterwood and group selection silvicultural systems; (iii) timber harvesting in second growth stands will employ treatments to restore late successional stand attributes; and (iv) in general, the desired future forest condition is uneven-aged forest".

The regulation goes on to set out five zones where $100 \%$ of the old growth must be reserved. The regulation does not define old growth zone but notes that such zones are "any zone identified on the forest stewardship zones map." It appears as though protection is ultimately discretionary (Forest Practices Board 2012; p. 9). To demonstrate equivalency with the statutory requirements, the Stillwater Forest Stewardship Plan had to set strategies and measurable targets addressing soil, water, biodiversity and other considerations. Minimum retention targets for coarse woody debris in stands of both old growth and second growth timber were identified (at s.61). Section 31 of the Stillwater Pilot Project Regulation requires that:

"Any forest practices carried out in the Stillwater area under a Stillwater pilot Forest Stewardship Plan must be carried out in a manner consistent with the Stillwater pilot Forest Stewardship Plan and any field variance referred to in section 32 ".

Violations of sections 31 or 34 of the Regulation are considered offences, with fines ranging up to $\$ 500000$ and/or imprisonment of up to two years.

Despite the fairly comprehensive legal process to incorporate OGF into forest management planning in British Columbia, there is no legally mandated provincial monitoring program to assess the effectiveness of old growth retention. Moreover, not all identified OGF in the province are legally protected.

\section{Conclusions}

First and foremost, it must be noted that Nova Scotia, New Brunswick and British Columbia have not integrated climate change adaptation, mitigation or resilience into their old-forest policies or regulatory frameworks. According to the 2014 Intergovernmental Panel on Climate Change (IPCC), terrestrial ecosystems are at risk from rising temperatures, drought, windstorms and the spread of invasive species. Policy makers need to develop adaptation and mitigation strategies to circumnavigate the associated risks (IPCC 2014). In old forests within the Acadian Forest Region, as elsewhere, the threat of invasive species such as the Hemlock Wooly Adelgid is imminent (CFIA 2017) and could be devastating.

Neither Nova Scotia nor New Brunswick has regulatory frameworks to require conservation or protection of OGF. Although Nova Scotia has still not reached the 8\% OGF conservation objective in all ecodistricts, it has met this goal in 32 of the 38 ecodistricts. There is currently no evidence to evaluate whether New Brunswick is meeting its conservation objective for maintaining $6-8 \%$ of old age classes for each of their forest communities.

Nova Scotia OGF policy could act as a model for other Maritime Provinces to demonstrate how science and ecological knowledge can be integrated into the conservation of OGF. The scoresheet is already being used as an OGF evaluation tool among conservation groups in all three Maritime Provinces. Nova Scotia has an old-forest database in GIS under development and an Old Forest Coordinator to oversee matters relating to the policy and other provinces would do 
well to follow that example. That being said, although there is an Old Forest Policy, there are currently no provisions to ensure that eight percent of the land within each of the 38 ecodistricts is preserved for OGF conservation or restoration, and there is no guarantee that an area protected within the eight percent of each ecodistrict will remain protected in perpetuity unless it is designated a protected area.

Similar to Nova Scotia, New Brunswick incorporates some science and ecological knowledge in its Old Forest Communities and Old Forest Wildlife Habitat definitions. By integrating empirical evidence that demonstrates the reliance of various vertebrate species on old-forest conditions, New Brunswick biologists could promote the preservation of some OFC and OFWH. This approach could be used by other provinces as a strategy for enhancing the protection of OGF as special habitats. However, New Brunswick allows harvesting of timber in $\mathrm{OFC}$ and OFWH, which would make it difficult for these areas to transition into OGF; this brings one to question the province's commitment to old-forest conservation.

Although located in a different biogeographical setting, British Columbia's regulatory approach offers useful examples for provinces in eastern Canada. Although complex, British Columbia has integrated Forest Stewardship Plans that promote the retention of OGF as legally enforceable tools for licensees in Old Growth Forest Management Areas. To ensure the protection or restoration of old forests, Maritime Provinces should integrate the best components of Nova Scotia's Old Forest Policy with a regulatory framework for licensees managing forests on Crown land similar to that in British Columbia

\section{Acknowledgements}

This project was undertaken with the financial support of the Government of Canada through the federal Department of Environment and Climate Change. The authors would also like to acknowledge the Habitat Conservation Fund, and the Department of Labour and Advanced Education for their financial contributions; Sean Lemoine from the Canadian Wildlife Service, Peter Bush from Nova Scotia Department of Natural Resources, Alain Belliveau from the Atlantic Canada Conservation Data Centre and Tom Herman, with Acadia University for reviewing this paper; and Olga Krobuk, Sam Mason, Eric Brown, Spencer Flynn, Robin McCourt, and Laura Boyd, law students who provided preliminary legal research.

\section{References}

Beazley, K., L. Smandych, T. Snaith, F. MacKinnon, P. AustinSmith and P. Duinker. 2005. Biodiversity considerations in conservation system planning: Map-based approach for Nova Scotia, Canada. Ecol. Appl. 15: 2192-2208

BCFLNRO. 1996a. [British Columbia Forest, Lands and Natural Resource Operations]. Environment Land Use Act. British Columbia Government. Chapter 117. Retrieved from BC Laws: http://www. bclaws.ca/civix/document/id/complete/statreg/96117_01\#section1

BCFLNRO. 1996b. [British Columbia Forest, Lands and Natural Resource Operations]. Park Act. British Columbia Government. Chapter 344. Retrieved from BC Laws: http://www.bclaws.ca/civix/ document/id/complete/stagreg/96344_01

BCFLNRO. 1996c. [British Columbia Forest, Lands and Natural Resource Operations]. Land Act. British Columbia Government. Chapter 245. Retrieved from BC Laws: http://www.bclaws.ca/civix/ document/id/complete /statreg/96245_01
BCFLNRO. 2000. [British Columbia Forest, Lands and Natural Resource Operations]. Protected Areas of British Columbia Act. British Columbia Government. Chapter 17. Retrieved from BC Laws: http://www.bclaws.ca/civix/document/id/complete/statreg/ 00017_01

BCFLNRO. 2001. [British Columbia Forest, Lands and Natural Resource Operations]. Stillwater Pilot Project Regulation. British Columbia Government. Retrieved from BC Laws: http://www. bclaws.ca/civix/document/id/1oo89/1oo89/96_2001

BCFLNRO. 2002. [British Columbia Forest, Lands and Natural Resource Operations]. Forest and Range Practices Act. British Columbia Government. Chapter 69. Retrieved from BC Laws: http://www.bclaws.ca/civix/document/id/complete/stareg/02069_01 BCFLNRO. 2004a. [British Columbia Forest, Lands and Natural Resource Operations]. Forest Planning and Practices Regulation. British Columbia Government. Retrieved from BC Laws: http:// www.bclaws.ca/civix/document/id/1oo83/12_14_2004

BCFLNRO. 2004b. [British Columbia Forest, Lands and Natural Resource Operations]. Forest Practices Code of British Columbia Act. British Columbia Government. Chapter 159. Retrieved from BC Laws: http://www.bclaws.ca/Recon/document/ID/freeside/ 00_96159_01

BCFLNRO. 2016. [British Columbia Forest, Lands and Natural Resource Operations]. Ecological Reserves Act. British Columbia Government. Chapter 103. Retrieved from BC Laws: htttp://www. bclaws.ca/civix/document/id/complete/statreg/96103_01

BCFLNRO. 2016. [British Columbia Forest, Lands and Natural Resources Operations]. Oil and Gas Activities Act. British Columbia Government. Chapter 36. Retrieved from BC Laws: http:// www.bclaws.ca/civix/document/id/complete/statreg/08036_01

Canadian Council of Forest Ministers. 2015. Province of New Brunswick. Retrieved from Sustainable Forest Management in Canada: https://www.sfmcanada.org/images/Publications/EN/ New_Brunswick_info_Provinces_and_territories_EN.pdf

CFIA. 2017. Hemlock Woolly Adelgid confirmed in Nova Scotia. Retrieved from Government of Canada: https://www.canada.ca/ en/food-inspection-agency/news/2017/08/hemlock_woolly_ adelgidconfirmedinnovascotia.html

CSA Group. 2016. Sustainable Forest Management: National Standard of Canada. Standards Council of Canada. pp. 1-79.

Davis, M., L. Gratton, J. Adams, J. Goltz, C. Stewart, S. Buttrick, N. Zinger, K. Kavanagh, M. Sims, and G. Mann. 2017. New England-Acadian forests. Retrieved from World Wildlife Fund: https://www.worldwildlife.org/ecoregions/na0410

Environmental Law Centre Clinic. 2013. An Old Growth Protection Act for British Columbia. Environmental Law Centre Society. pp. 1-18.

Forest Practices Board. 2012. Conserving Old-growth Forests in BC: Implementation of old-growth retention objectives under FRPA, Special Investigation, Forest Practices Board. pp. 1-32.

FSC. 2008. Certification Standards for Best Forestry Practices in the Maritimes Region. Toronto: FSC. pp. 1-96.

Hilbert, J. and A. Wiensczyk. 2007. Old-growth definitions and management: A literature review. J. Ecosyst. Manage. 8(1): 15-31.

IPCC. 2014. [Intergovernmental Panel on Climate Change]. Impacts, Adaptation and Vulnerability. 1820 p.

Leckie, D.G., M.D. Gillis and M.A. Wulder. 2002. Deforestation estimation for Canada under the Kyoto Protocol: A design study. Can. J. Remote Sens. 28(5): 672-678.

Loo, J.and N. Ives. 2003. The Acadian forest: Historical condition and human impacts. Forest. Chron. 79(3): 462-474.

Luyssaert, S., E.D. Schulze, A. Börner, A. Knohl, D. Hessenmöller, B.E. Law et al. 2008. Old-growth forests as global carbon sinks. Nature 455(7210): 213-215.

Miller, L. and S. Nadeau. 2016. Perceptions of public land governance from two Canadian provinces: How is the social agenda being met through sustainable forest management? Land Use Policy. 
Retrieved from Science Direct: http://www.sciencedirect.com/science/article/pii/S024837716311632

Miller, L. F., and S. Nadeau. 2017. Participatory processes for public lands: Do provinces practice what they preach? Ecol. Soc. 22(2):19. Retrieved from Ecology and Society: http://www.ecologyandsociety.org/vol122/iss2/art19/

Mosseler, A., J.A. Lynds and J.E. Major. 2003. Old-growth forests of the Acadian Forest Region. Environ. Rev. 11(S1): S47-S77.

Moyer, J. M., R.J. Owen and P.N. Duinker. 2008. Forest values: A framework for old-growth forest with implications for other forest conditions. Open For. Sci. J. 1: 27-36.

Natural Resources Canada. 2016. Forest Inventory. Retrieved from Statistical Data: ttps://cfs.nrcan.gc.ca/statsprofile

NBDNR. 1980. [New Brunswick Department of Natural Resources]. Crown Lands and Forest Act, Government of New Brunswick. Chapter C-38.1. Retrieved from Government of New Brunswick. http://laws.gnb.ca/en/ShowTdm/cs/C-38.1//

NBDNR. 2002. [New Brunswick Department of Natural Resources]. Protected Natural Areas Act, Government of New Brunswick. Chapter P-19.01. Retrieved from Government of New Brunswick. http://laws.gnb.ca/en/ShowTdm/cs/P-19.01//

NBDNR. 2011. [New Brunswick Department of Natural Resources]. Conservation Easements Act, Government of New Brunswick. Chapter 2011, c.130. Retrieved from Government of New Brunswick. http://laws.gnb.ca/en/ShowTdm/cs/2011-c.130//

NBDNR. 2013. [New Brunswick Department of Natural Resources]. Old Forest Community and Old-Forest Wildlife Habitat Definitions for New Brunswick 2012, Government of New Brunswick. pp. 1-12.

NBDNR. 2014a. [New Brunswick Department of Natural Resources]. New Brunswick Strategy for Crown Lands and Management, Government of New Brunswick. 5 p.

NBDNR. 2014b. [New Brunswick Department of Natural Resources]. Forest Management Manual for New Brunswick Crown Lands: Results-Based Forestry Option, Government of New Brunswick. pp. 1-26.

NBDNR. 2014c. [New Brunswick Department of Natural Resources]. Schedule G - Licensee Performance Evaluation Criteria, Government of New Brunswick. 2 p.

NSDNR. 1989. [Nova Scotia Department of Natural Resources]. Crown Lands Act. Government of Nova Scotia. Chapter 114. Retrieved from Government of Nova Scotia: http:// nslegislature.ca/legc/statues/crownlan.htm

NSDNR. 1989. [Nova Scotia Department of Natural Resources]. Forests Act. Government of Nova Scotia. Chapter 179. Retrieved from Government of Nova Scotia: http://nslegislature.ca/legc/ statutes/forests.htm
NSDNR. 1989. [Nova Scotia Department of Natural Resources]. Forest Enhancement Act. Government of Nova Scotia. Chapter 178. Retrieved from Government of Nova Scotia:

NSDNR. 1989. [Nova Scotia Department of Natural Resources]. Special Places Protection Act. Government of Nova Scotia. Chapter 438. Retrieved from Government of Nova Scotia: http://nslegislature.ca/legc/statutes/specplac..htm

NSDNR. 1998. [Nova Scotia Department of Natural Resources]. Wilderness Areas Protection Act. Government of Nova Scotia. Chapter 27. Retrieved from Government of Nova Scotia: http://nslegislature.ca/legc/statutes/wildarea.htm

NSDNR. 2001. [Nova Scotia Department of Natural Resources]. Conservation Easements Act. Government of Nova Scotia. Chapter 18. Retrieved from Government of Nova Scotia: http://nslegislature. $\mathrm{ca} /$ legc/statutes/conservation\%20easements.pdf

NSDNR. 2012. [Nova Scotia Department of Natural Resources]. Nova Scotia's Old Forest Policy. Government of Nova Scotia. pp. 1-15. Retrieved from Government of Nova Scotia: http://novascotia.ca/ natr/library/forestry/reports/Old-Forest-Policy-2012

Pachauri, R.K., L. Meyer, G.K. Plattner and T. Stocker. 2015. IPCC 2014: Climate Change 2014: Synthesis Report. Contribution of Working Groups I, II and III to the Fifth Assessment Report of the Intergovernmental Panel on Climate Change. IPCC. pp. 1-151.

Pesklevits, A., P.N. Duinker and P.G. Bush. 2011. Old-growth Forests: Anatomy of a Wicked Problem. Forests 2(1): 343-356.

Rowe, J.S. 1972. Forest regions of Canada. Department of the Environment, Canadian Forest Canadian Forest Service. Publication No. 1300.

Sample, V.A., W. Price and C.M. Mater. 2003. Certification on public and university lands: evaluations of FSC and SFI by the forest managers. J. Forest. 101(8): 21-25.

Stewart, B.J., P. D. Neily, E.J. Quigley and L.K. Benjamin. 2003. Selected Nova Scotia old-growth forests: Age, ecology, structure, scoring. Forest. Chron. 79(3): 632-644.

Stewart, B.J. and P.D. Neily. 2008. Implementation of Nova Scotia Interim Old Forest Policy for Crown Land "A Status Report". Nova Scotia Department of Natural Resources. pp. 1-23. Retrieved from Government of Nova Scotia: http://novascotia.ca/natr/library/ forestry/reports/state-of-forest-old-growth.pdf

SFI. 2015. [Sustainable Forestry Initiative]. SFI 2015-2019 Forest Management Standard. Sustainable Forestry Initiative. pp. 1-13.

Wirth, C., C. Messier, Y. Bergeron, D. Frank and A. Fankhänel. 2009. Old-growth forest definitions: A pragmatic view. In: OldGrowth Forests (pp. 11-33). Springer Berlin Heidelberg. 